\title{
Philosophical Views of Thomas Jefferson on Religion and Politics
}

\author{
Yaroslav Sobolievskyi \\ Ph.D., Assistant Professor, Taras Shevchenko National University of Kyiv \\ (Kyiv, Ukraine) \\ E-mail: yasobolevsky@gmail.com \\ https://orcid.org/0000-0001-8251-2744
}

The article examines the philosophical views of the American enlightener Thomas Jefferson on religion and politics. The social and political ideas of the philosopher are studied; the main attention is paid to the study of the letters of the philosopher and the demonstration of views on the problem of freedom of religion and the basis of morality. The main ideal of the thinker is freedom, to which he aspires both in politics and in religion. Freedom and reason bring people closer to a pure religion that glorifies only one God, and focuses on inner experience, and not on rituals. In matters of ethics, Thomas Jefferson tended to the existence of an innate moral sense, which does not depend on the knowledge of the basics of ethics. God created people, and laid the foundations of moral behavior in us, and therefore it is erroneous to think that morality is the result of scientific searches of thinkers. The best existing ethics Jefferson believes Christian ethics, which has strengthened monotheism, it is not aimed at an act, but on a motive, but unlike ancient ethics, Christian doctrine has a universal character. Philosophical views of Jefferson on the problem of politics and religion are revealed through moral philosophy. Studying the heritage of antiquity allowed the philosopher to analyze Christianity and other world religions for worldview.

Keywords: Thomas Jefferson; American philosophy; American Enlightenment; religion; politics

Received: October 1, 2018; accepted: October 28, 2018

Ukrainian Policymaker, Volume 3, 2018: 58-64.

https://doi.org/10.29202/up/3/8

The personality of Thomas Jefferson (1743-1826) is well studied by domestic political scientists, historians and Americanists. $\mathrm{He}$ is an outstanding figure of the American Revolutionary War; he became an author of the most important text in the history of the United States - United States Declaration of Independence, 1776. Like other enlighteners, Thomas Jefferson is a historical person who was thoroughly studied in America, and being one of the founding fathers of the state, he also became the third president of the United States (1801-1809). He was an outstanding politician, diplomat and philosopher of the American Enlightenment. He headed the committee to write the Declaration of Independence, which included wellknown thinkers, politicians and philosophers such as: second president John Adams (1735-

(C) Sobolievskyi, Yaroslav, 2018 
1826), Benjamin Franklin (1706-1790), lawyer and politician Roger Sherman (1721-1793) and diplomat Robert R. Livingston (1746-1813). Communication and correspondence with famous intellectuals of his time formed a multi-faceted worldview of the thinker. He was interested in the ideas of secularism, the problems of religion, religious freedom, education, ethics, the teachings of the ancient philosophers of Plato and the Epicureans, the teachings of the English philosophers John Locke (1632-1704) and Anthony Ashley Cooper, $3^{\text {rd }}$ Earl of Shaftesbury (1671-1713), the relation of matter and thinking, matter and sensations.

The purpose of the article is to implement the historical and philosophical reconstruction of Thomas Jefferson's basic philosophical views on politics. In search of influence on the philosophical views of the thinker, one must mention the fascination with the ancient heritage of Ancient Greece and Rome. This interest determined the architecture, literature and politics of the United States of America in the $19^{\text {th }}$ century. Ancient ideals of freedom and democracy impressed Thomas Jefferson, who sought to build a young country in the style of classical classicism. His enlightenment ideals were embodied in the creation on the basis of his own collection of books the Library of Congress and at the foundation of the University of Virginia.

Education philosopher received a philosophical department in The College of William \& Mary, but from his youth he knew Latin, Greek and French. In college, the future president of the country studied mathematics, physics and metaphysics, studying the work of the physicist Sir Isaac Newton (1643-1727), the philosophy of Sir Francis Bacon (1561-1626), the philosophy of John Locke (1632-1704); he was fond of British empiricism. Professor of History at the University of Virginia Merrill D. Peterson (1921-2009), is a well-known compiler of Thomas Jefferson's works. He notes that the thinker considered these three philosophers to be the greatest people in history [Peterson, 1984: 1236]. The biographer of Thomas Jefferson, Kevin J. Hayes in the book The Road to Monticello: The Life and Mind of Thomas Jefferson, 2008, had confirmed that [Hayes, 2008: 10]. The author depicts the spiritual and intellectual development of Thomas Jefferson, focusing on ideas that reveal the full range and depth of the philosopher's interests, from popular Aesop fables and Horace, to Ovid and Virgil. The interest of the American Enlightenment to the legacy of British empiricism is not accidental, because the ideas of experimental science and political philosophy interested intellectuals on both sides of the Atlantic.

First of all, we should mention those who studied the philosophy of the American Enlightenment. American historian of science, author of many books on the history of science and philosophy Ierome Bernard Cohen (1914-2003), author of the book Science and the Founding Fathers: Science in the Political Thought of Jefferson, Franklin, Adams, and Madison, 1995. With Bernard Bailyn, who is the author of The Ideological Origins of the American Revolution, 1967, Faces of Revolution: Personalities and Themes in the Struggle for American Independence, 1990. With Robert A. Ferguson, who is the author of The American Enlightenment, 1750-1820, 1997, with Henry F. May, who is the author of The Enlightenment in America, 1978, and there are lots of others.

In the Soviet period, philosophers studied the American Enlightenment and the political philosophy of the $18^{\text {th }}$ century, since this period corresponded to the official doctrine of the historical development of communism, as a stage in which America struggled with the relic of religion. In 1968-1969, when diplomatic relations between the countries were tense, in the multivolume edition of the Philosophical Heritage two volumes appeared: American Enlighteners: Selected Works in 2 Volumes, compiled by Nikolay Goldberg with an introductory article by Bernard Bykhovsky. In 1976, the authors Grigory Sevostyanov and Anatoly Utkin 
published the work Thomas Jefferson, in which they depicted the historical portrait of an outstanding ideologist. The authors used a large number of books to reproduce the multifaceted image of Thomas Jefferson. The author of a new reading of the biography of Thomas Jefferson, a thorough analysis of the relationship with Benjamin Franklin, George III and other outstanding figures of the time became Vladimir Sogrin. He dedicated a monograph to this problem called Jefferson. Man, Thinker, Politician. There is an important book written by Vladimir Pechatnov, Hamilton and Jefferson, in which the researcher highlights the life and work of prominent politicians, including Thomas Jefferson. Also worth mentioning is the book by Anyur Karymsky The Revolution of 1776 and the Establishment of American Philosophy, published in 1976. After the Second World War, a new "probable adversary" appeared before the Soviet Union. "It was necessary for the Soviet leadership to know the philosophy of America, how people think there, what they dream about, what they want" [Sobolievskyi, 2017: 102]. The study of American philosophy made it possible to better know the Americans themselves.

Researcher of the philosophical heritage of Thomas Jefferson, Adrienne Koch, (19131971) in the preface to his book The Philosophy of Thomas Jefferson, 1943, wrote about the figure of the thinker:

"This is, in one sense, defensible; but it dwarfed our understanding of Jefferson's intellectual lineage and fostered our ignorance of the world in which he was mentally at home - his philosophic outlook. Not all statesmen can be expected to have philosophy, or to be philosophers. Jefferson, in the richness of his nature, happened to possess a speculative vein, luckily fostered by a favorable cultural tradition. He was a man so vitally interested in exploring ideas that to deny him the title of "philosopher" is to argue adherence to a prejudiced definition of the term" [Koch, 1943: 3].

Philosophical ideas of Thomas Jefferson are described in his numerous letters, as well as in the works: Autobiography, 1821, A Summary of the Rights of British America, 1774, Notes on the State of Virginia, 1781, and others. The work of the philosopher A Summary of the Rights of British America ensured him the status of a deep thinker and a fighter for equality. To date, on the website of the National Archive of the United States, more than 20,000 letters written by Thomas Jefferson himself have been publicly available, and even more letters addressed to the philosopher.

Thomas Jefferson was an adherent of the classical res publica, analyzing its principles in social life in its numerous aspects, such as local government, education, law, the army and the protection of rights. In his philosophical and religious views, Thomas Jefferson was inclined to the popular deism among American enlighteners.

Like most American educators, the philosopher sees reason as the foundation of philosophy, not authority. It is reason that is the only reliable criterion of truth in the process of cognition. A well-known supporter of the ideas of secularism believed that the cause of faith could not be controlled by the state; therefore, the idea of freedom of religion impressed the thinker.

According to Thomas Jefferson, the state as such is a voluntary association of people to protect their civil interests, and therefore no one has the power to order someone to believe or not to believe. The concept of faith becomes irrelevant. In his records of 1776, Thomas Jefferson refers to the work of John Locke, he writes about the church: 
"[a church] is a voluntary society of men, joining [themselves] together of their own accord, in order to the [publick] worshipping of god in such a manner as they judge [accept] able to him \& effectual to the salvation of their souls. [it is] voluntary because no man is by nature bound to any church" [The Papers of Thomas Jefferson, vol. 1, 1760-1776, 1950: 544-550].

The thinker argues that God, being good, did not consider it better to spread his religion through political persecution or punishment. The philosopher thinks that God, being almighty, decided to carry his word, influencing the human mind. Thomas Jefferson believes that no church is better or worse, right or wrong. The philosopher gives a comparison in which he argues that as Arminian or Calvinist churches cannot argue about righteousness. After all, neighbors do not argue about the traditions of household farming. The state cannot prohibit being healthy or poor, just as it cannot dictate faith, and therefore care for the soul is entrusted solely to the shoulders of a person. Successfully drawing parallels, Thomas Jefferson compares the believer to the peasant, who trusts the goods to the state repository. In the event of an unforeseen situation, the state can return it to them, but how can the state offer the Kingdom of God? A state cannot promise hell or heaven, it means it cannot indicate how to go to them. The road to heaven is unknown to anyone, and therefore, the philosopher asserts, no one is able to guide in faith. Errors often dominated in this or that power, different state institutions differently implement their policies. If the secularism of Thomas Jefferson on the one hand separates religion and politics, on the other, he unites them as undeniable human rights. So, in search of an answer to the question "what is truth?" The philosopher defines it, as "Truth is the proper \& sufficient antagonist to error" [The Papers of Thomas Jefferson, vol. 1, 1760-1776, 1950: 544-550].

In the Middle Ages, the Christian opposition was almost non-existent, so the religious monopoly did not develop ideologically, because only where there is debate - there can exist, as the philosopher says, pure religion. All Christian religious texts are written by people who were already Christians, and therefore to become a Christian, Thomas Jefferson concludes, the text and strict observance of laws is not mandatory, because the law is written in the heart. Thus, the traditional view of Thomas Jefferson as a critic of Christianity is fair, but in part. The main ideal of the philosopher is freedom, which he seeks both in politics and in religion, it is freedom and reason that will bring people closer to pure religion. The philosopher calls the main features of such a pure religion: 1) the knowledge of only one God;2) a clear understanding of one's duty and the best system of moral behavior; 3 ) release from the layering of the burdensome external form of religious worship; 4) the motivation for a godly life and future bliss, as a reward for virtue.

In order to be free to talk about religion, you need to have a prepared mind, says Thomas Jefferson. One should be cautious about these issues; however, one must boldly cast aside fears and prejudices: «Question with boldness even the existence of a god; because, if there be one, he must more approve the homage of reason, than that of blindfolded fear» [The Papers of Thomas Jefferson, vol. 12, 7 August 1787-31 March 1788, 1955: 14-19].

These lines were written by Thomas Jefferson in a letter to his nephew Peter Carr (17701815) in 1787. In this letter the philosopher gives life advice to a young man, including advice on literature, languages and philosophy. He edifies, arguing that the result of the study of the religions of the world can be two opposite conclusions about the existence of God: 
1. If the study of religions assures us that there is no God, it will increase interest in ethics and charity;

2. If the study of religions assures us that God exists, the realization that He is watching us will provide additional moral support.

The philosopher gives advice: do not believe anything, do not object to anything: "Your own reason is the only oracle given you by heaven, and you are answerable not for the rightness but uprightness of the decision" [The Papers of Thomas Jefferson, vol. 12, 7 August 1787-31 March 1788, 1955: 14-19]. In the letter, the philosopher formed a list of literature that, in his opinion, contains the best considerations about the nature of religion and politics and morality, where he recalls John Locke, David Hume, Voltaire, Socrates, Cicero, Helvetius, Lucretia, and others.

In questions of the Moral philosophy, Thomas Jefferson tended to believe in the existence of an innate moral sense of man. In a letter to P. Carr, he discusses the education of a young man. In addition to the need to study useful sciences, the philosopher doubts the usefulness of moral philosophy. From the letter, it becomes obvious that, in the opinion of the thinker, the study of ethics is only a waste of time. Since when God created us, he undoubtedly must lay the foundations of moral behavior in us, and therefore it is erroneous to consider that morality is the result of scientific searches of thinkers.

According to Thomas Jefferson:

"Man was destined for society. His morality therefore was to be formed to this object. He was endowed with a sense of right and wrong merely relative to this. This sense is as much a part of his nature as the sense of hearing, seeing, feeling; it is the true foundation of morality, and not the truth, \&c., as fanciful writers have imagined. The moral sense, or conscience, is as much a part of man as his leg or arm" [The Papers of Thomas Jefferson, vol. 12, 7 August 1787-31 March 1788, 1955: 14-19].

So we can conclude, first, that a man for Thomas Jefferson is a social being, and secondly, according to this analogy, if every person has different senses, then maybe there is a different moral development feelings. According to the philosopher's conviction, this feeling, like the others, can be trained and improved. Morality is in the subordination of the mind, but with the fate of so-called common sense.

The example he gives is that if the same moral task is asked to solve a peasant and a professor of ethics, they both will easily solve it. Perhaps, because there are more artificial rules in the professor's mind, he needs more time for this. Giving advice to a young relative to read the best books on ethics, Tomas Jefferson gives a setting that sounds like a maxim: "Consider every act of this kind as an exercise which will strengthen your moral faculties, and increase your worth" [The Papers of Thomas Jefferson, vol. 12, 7 August 1787-31 March 1788, 1955: 14-19]. Accordingly, every moral act strengthens the innate moral sense.

In a letter to the social and political figure Benjamin Rush (1746-1813), Thomas Jefferson, in order to assess the moral teachings of Christians, suggests analyzing other ethical teachings of antiquity. As a result of his own searches, Thomas Jefferson wrote the work of Syllabus, 1803. In this book, the philosopher states that "Philosophers ... Their precepts related chiefly to ourselves, and the government of those passions which, unrestrained, would disturb our tranquility of mind" [The Papers of Thomas Jefferson, vol. 40, 4 March -10 July 1803, 2013: 253-255]. However, according to the American philosopher, the teachings of the ancient sages 
were intended for a small circle of friends and did not have a universal character. They taught patriotism, goodwill and justice, which were not very similar to the real desire for the good of another, but they did not teach much about love and mercy to their neighbor. Even the political philosophy of antiquity considered justice an injustice. We can assume that the philosopher criticizes the ancient thinkers for a certain isolation of abstract thoughts from a concrete existence. Similarly, the ethics of the Jews are issued to Thomas Jefferson imperfect, contrary to reason. Rethinking Judaism came along with the figure of Jesus, who had no education, whose origins are little known, however, his righteous life serves as a worthy example for everyone. Comparing Jesus and Socrates, Thomas Jefferson notes that both did not leave the texts, only followers, and the cultural and religious conditions in which their teachings originated are similar to each other. The political situation of the time was such that the authorities opposed their teachings. The authorities demanded the political and real suicide of Socrates, who taught goodness, obedience and duty. Jesus was given power for execution, for a similar teaching.

The question of divine origin is not of interest to Thomas Jefferson, since Jesus, who was relatively young, and as a young man, decided to reform the state of things. His teaching collided with the «altar and throne».

For many years of translation, the teaching of Jesus could not but change. Therefore, you can only talk about the current state of Christianity, its essence:

1. Christianity strengthened monotheism and developed the doctrine of the attributes of God.

2. Christian morality is more general than philosophers and Jews; it is inherent in philanthropy towards all people, and not a certain group of friends or family.

3. The teachings of ancient philosophers and Jews are of a practical nature and relate mainly to actions, not opinions.

4. The Christian teaching was directed to the future and had a goal, unlike other ethical teachings [The Papers of Thomas Jefferson, vol. 40, 4 March -10 July 1803, 2013: 253-255].

Philosophy for Thomas Jefferson, even in the time of the Pythagoreans and Neoplatonists with their mysticism, performed the function of balance in the person of the Epicureans and academicians, and thus science flourished [The Papers of Thomas Jefferson, vol. 1, 1760 1776, 1950: 544-550]. However, awareness of ancient philosophy did not cause unambiguous enthusiasm. It is interesting to note that the magnum opus of the ancient philosopher Plato

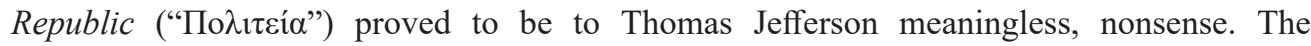
philosopher allows himself such an assessment, explaining that he was preparing for a serious reading of the work for a long time, and does not understand why the classics of philosophical thought, such as Cicero, could admire it. Calling Plato a sophist, Thomas Jefferson is convinced that the outstanding ideas of the ancient philosopher were preserved because they were, first, written in an exquisite style, and, secondly, because they assimilated well in Christianity:

"His foggy mind, is forever presenting the semblances of objects which, half seen through a mist, can be defined neither in form or dimension. Yet this which should have consigned him to early oblivion really procured him immortality of fame \& reverence. the Christian priesthood, finding the doctrines of Christ levelled to every understanding, and too plain to need explanation, saw, in the mysticisms of Plato, materials with which they might build up an artificial system which might, from its indistinctness, admit everlasting controversy, give employment for their order, and introduce it to profit, 
power \& pre-eminence" [The Papers of Thomas Jefferson, Retirement Series, vol. 7, 28 November 1813 to 30 September 1814, 2010: 451-455].

Thomas Jefferson believes that further research has not made Plato's ideas clearer, but the ideas of Jesus are clear to all. They make sense, and the work of the ancient author is not theirs. At the same time, Thomas Jefferson understands that criticizing Plato is the same as that of the holy fathers, and his ideas are subjected to aggressive criticism.

\section{[D] References}

Hayes, Kevin J. The Road to Monticello: The Life and Mind of Thomas Jefferson. Oxford: Oxford University Press, 2008.

Jefferson, Tomas. Autobiography; Notes on the State of Virginia. Leningrad: Nauka, 1990. (In Russian).

Koch, Adrienne. The philosophy of Thomas Jefferson. New York: Columbia university press, 1943.

Pechatnov, Vladimir. Hamilton and Jefferson. Moscow: International relations, 1984. (In Russian).

Peterson, Merrill D. Thomas Jefferson: Writings. New York: Library of America, 1984.

Sevostyanov, Grigory, and Anatoly Utkin. Tomas Jefferson. Moscow: Musl, 1976. (In Russian).

Sobolievskyi, Yaroslav. Soviet and Ukrainian Studies of American Philosophy: Translation of

Philosophical Texts. Future Human Image, Vol. 9. Kyiv: ISPC, 2018. 100-106. https:// doi.org/10.29202/fhi/9/10

Sogrin, Vladimir. Jefferson: Man, thinker, politician. Moscow: Nauka, 1989. (In Russian).

The Papers of Thomas Jefferson, Retirement Series, vol. 7, 28 November 1813 to 30 September 1814. Edited by J. Jefferson Looney. Princeton: Princeton University Press, 2010.

The Papers of Thomas Jefferson, vol. 1, 1760-1776. Edited by Julian P. Boyd. Princeton: Princeton University Press, 1950.

The Papers of Thomas Jefferson, vol. 12, 7 August 1787-31 March 1788. Edited by Julian P. Boyd. Princeton: Princeton University Press, 1955.

The Papers of Thomas Jefferson, vol. 40, 4 March -10 July 1803. Edited by Barbara B. Oberg. Princeton: Princeton University Press, 2013. 